Prepared for the U.S. Department of Energy under Contract DE-AC05-76RL01830

\title{
Assessment of Impacts from Adopting the 2009 International Energy Conservation Code for Residential Buildings in Michigan
}

RG Lucas

October 2009

Pacific Northwest

NATIONAL LABORATORY

Proudly Operated by Battelle Since 1965 


\section{DISCLAIMER}

This report was prepared as an account of work sponsored by an agency of the United States Government. Neither the United States Government nor any agency thereof, nor Battelle Memorial Institute, nor any of their employees, makes any warranty, express or implied, or assumes any legal liability or responsibility for the accuracy, completeness, or usefulness of any information, apparatus, product, or process disclosed, or represents that its use would not infringe privately owned rights. Reference herein to any specific commercial product, process, or service by trade name, trademark, manufacturer, or otherwise does not necessarily constitute or imply its endorsement, recommendation, or favoring by the United States Government or any agency thereof, or Battelle Memorial Institute. The views and opinions of authors expressed herein do not necessarily state or reflect those of the United States Government or any agency thereof.

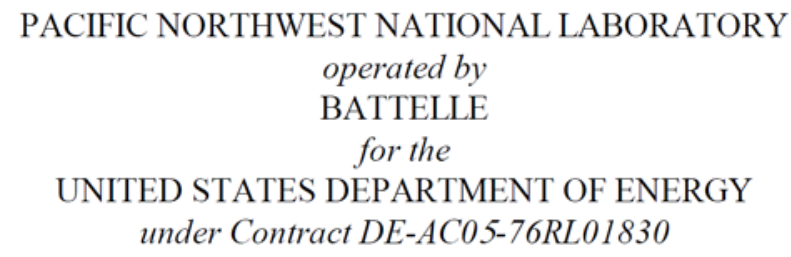

Printed in the United States of America

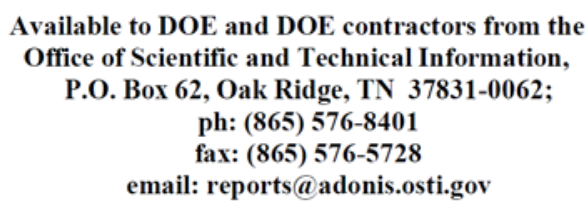

Available to the public from the National Technical Information Service, U.S. Department of Commerce, 5285 Port Royal Rd., Springfield, VA 22161 ph: (800) 553-6847 fax: (703) 605-6900

email: orders@ntis.fedworld.gov

online ordering: http://www.ntis.gov/ordering.htm

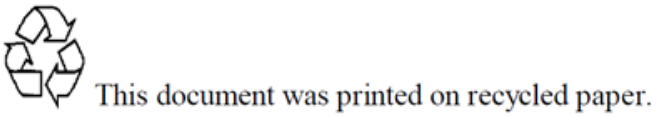


PNNL-18770

\section{Assessment of Impacts from Adopting the 2009 International Energy Conservation Code for Residential Buildings in Michigan}

RG Lucas

October 2009

Prepared for U.S. Department of Energy under Contract DE-AC05-76RL01830

Pacific Northwest National Laboratory Richland, Washington 99352 



\section{Summary}

The Michigan Uniform Energy Code (MUEC) sets a mandatory statewide building energy efficiency code for the construction of residential buildings. The state of Michigan Department of Energy, Labor, and Economic Growth requested a comparison of the MUEC to another code, the 2009 Edition of the International Code Council's (ICC) International Energy Conservation Code (IECC) (ICC 2009). The U.S. Department of Energy (DOE) has requested Pacific Northwest National Laboratory (PNNL) to estimate the energy savings, economic impacts, and pollution reduction from adopting the 2009 IECC. This report addresses the impacts for low-rise residential buildings only.

The analysis indicates that homes built to meet the 2009 IECC requirements will save Michigan homeowners money by reducing energy costs by more than the construction-related cost increases. The main impact is from improved duct sealing verified by duct system leakage testing and increased duct

insulation. Building enclosure insulation levels and window requirements are largely unchanged from the current state code, although there are some increases and some decreases in insulation requirements. Homeowners with a typical mortgage should realize a net positive cash flow within a few years or less in most cases. Construction cost increases and energy savings will vary depending on many factors, including location, fuel prices, house size and characteristics, material and labor costs, and the energy efficiency measures used to comply with both the MUEC and the 2009 IECC. 


\section{Contents}

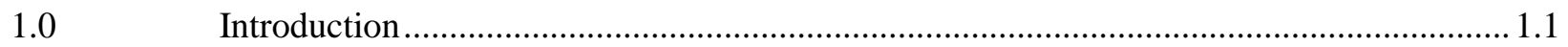

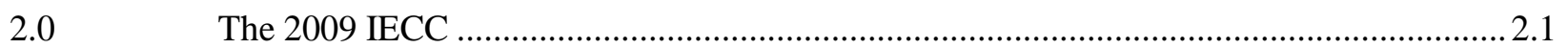

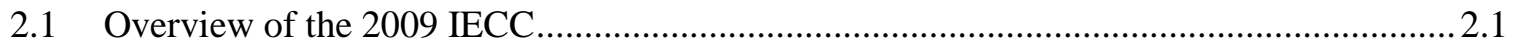

2.2 Differences Between the MUEC and the 2009 IECC …................................................... 2.3

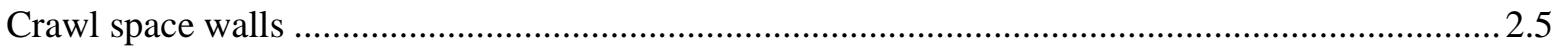

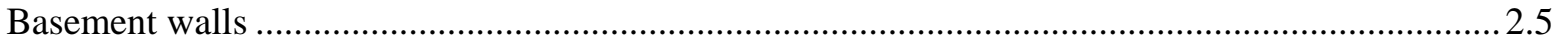

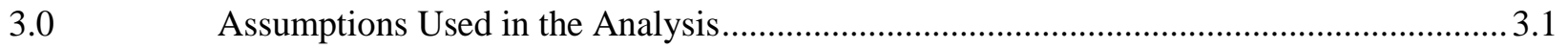

Impacts from Adopting the 2009 IECC in Michigan ................................................... 4.1

4.1 Construction Cost Impacts ....................................................................................... 4.1

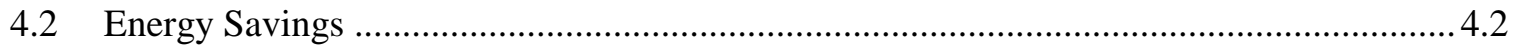

4.3 Economic Impacts as specified by the Stille-DeRossett-Hale Single State Code

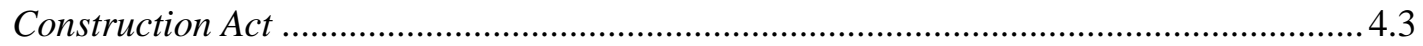

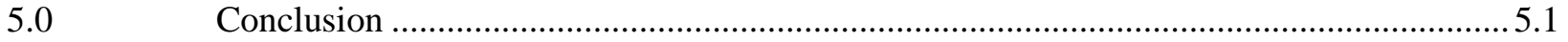

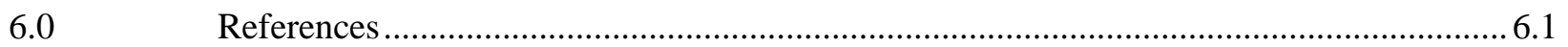




\section{Figures}

2.1 Prescriptive Envelope Requirements in the 2009 IECC ........................................................ 2.3

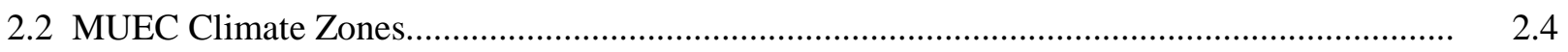

\section{Tables}

2.1 MUEC and 2009 IECC Prescriptive Envelope Requirements ................................................ 2.5

4.1 Construction Costs (Incremental Relative to MUEC requirements) for 2009 IECC Energy Efficiency

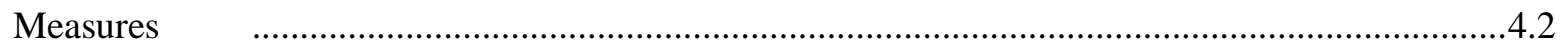

4.2 Annual Heating and Cooling Energy Cost and Savings from Compliance with IECC .............. 4.3

4.3 Impacts to Consumers' Cash Flow from Compliance with IECC ......................................... 4.5 


\subsection{Introduction}

The state of Michigan requested a comparison of the MUEC to the 2009 Edition of the International Code Council's (ICC) International Energy Conservation Code (IECC) (ICC 2009). It was requested that the seven year cost/benefit economic criterion of the Stille-DeRossett-Hale Single State Code Construction Act be used. This report provides estimates of the energy savings and economic impacts from adopting the 2009 IECC for low-rise residential buildings.

Section 2 of this report contains an overview of the 2009 IECC. Assumptions used in the analysis are discussed in Section 3. Section 4 discusses the impacts from adopting the 2009 IECC for residential buildings in Michigan. Section 5 provides conclusions from the analysis and Section 6 contains a list of publications referenced in this report. 


\subsection{The 2009 IECC}

This chapter summarizes requirements in the 2009 IECC and key differences between the current Michigan energy code and the 2009 IECC.

\subsection{Overview of the 2009 IECC}

The IECC is a nationally recognized model code that contains requirements for the energy efficient design and construction of all building types, in all U.S. locations. Chapter 4 of the 2009 IECC contains specific requirements for residential buildings, and Chapters 1 and 2 contain general information applicable to both residential and commercial buildings. The residential building category includes single-family houses, duplexes, and multifamily residential buildings three stories or less above-grade in height. Multifamily buildings include apartments, condominiums, and dormitories, but do not include hotels and motels. Commercial buildings contain separate requirements from residential buildings and are addressed in Chapter 5 of the code.

For residential buildings, the IECC addresses energy use from space heating, space cooling, water heating, and lighting (the current MUEC includes the first three but not lighting). Energy savings resulting from the IECC will primarily be from reduced space heating, air conditioning, and lighting; current construction practice is assumed to comply with the minimal requirements in the IECC for water heating. There will be some lighting savings over the short run from the efficient lighting requirements in the IECC, but mandatory Federal light bulb standards starting in the 2012-2014 timeframe will eventually make the IECC requirements less relevant.

The IECC sets requirements for the thermal and solar heat gain performance levels for the building envelope. Except for windows, skylights and doors, requirements are expressed in terms of both thermal performance and insulation R-values. The envelope includes walls, windows and skylights, doors, ceilings, floors, and the perimeter of slab-on-grade foundations. As with the current MUEC, these envelope requirements become more stringent as the climate becomes colder, so more insulation and better windows are required in northern Michigan compared to southern Michigan. All openings, such as penetrations and cracks in the building envelope, must be sealed.

The IECC contains limited requirements for space heating and cooling systems and domestic water heating systems (for showers, sinks, clothes washing, etc.). Efficiency requirements for mechanical equipment types (furnaces, boilers, heat pumps, etc.) that are part of these systems are set by Federal law and cannot be directly altered by state codes unless a waiver is granted. The IECC sets requirements for mechanical system controls, duct sealing and insulation, piping insulation, circulating hot water systems, mechanical ventilation and equipment sizing.

The IECC has important requirements for sealing and insulating ductwork that passes through unconditioned spaces, such as unheated basements and attics. A major new requirement in the IECC not in the MUEC is that these ducts have to be tested for air leakage after installation. 
As with the current MUEC, the IECC contains three alternative compliance paths: simplified prescriptive requirements, a total building envelope UA (U-factor multiplied by area) approach, and a simulated performance approach. The IECC allows trade-offs where some energy efficiency measures can fall below code requirements for a specific measure if other measures exceed code requirements. The IECC allows these trade-offs as long as the estimated total annual energy cost does not increase. ${ }^{1}$ However, the 2009 IECC does not permit trade-offs for higher-efficiency furnaces, air conditioners or other equipment. Several relatively easy-to-use software products are available to assist in designing a building that complies with the IECC, including DOE's free REScheck ${ }^{\mathrm{TM}}$ software (DOE 1995).

The 2009 IECC has a simple prescriptive compliance path that applies to all residential buildings. There is a single table of requirements for insulation R-values and window U-factors and SHGC, and a second table of equivalent U-factors that apply to all low-rise residential buildings (the same requirements apply to single-family and multifamily). In contrast, the MUEC has this type of compliance path of R-values and U-factors, but the user had to calculate the window-to-wall area ratio to determine the appropriate table of requirements.

The 2009 IECC has a map-based format for presenting code requirements that vary by climate, where the appropriate climate zone can easily be determined from a county map of the U.S. The 2006 IECC has eight primary climate zones, from hot locations (i.e., southern Florida) to very cold locations (i.e., northern Alaska). Michigan falls into three zones (Zones 5, 6, and 7). County borders set climate zone boundaries. Figure 2.1 shows the climate zones in Michigan and the main prescriptive envelope requirements for the 2009 IECC.

\footnotetext{
${ }^{1}$ Local jurisdictions may, at their discretion, require that source energy use (Btu) be balanced rather than energy cost.
} 


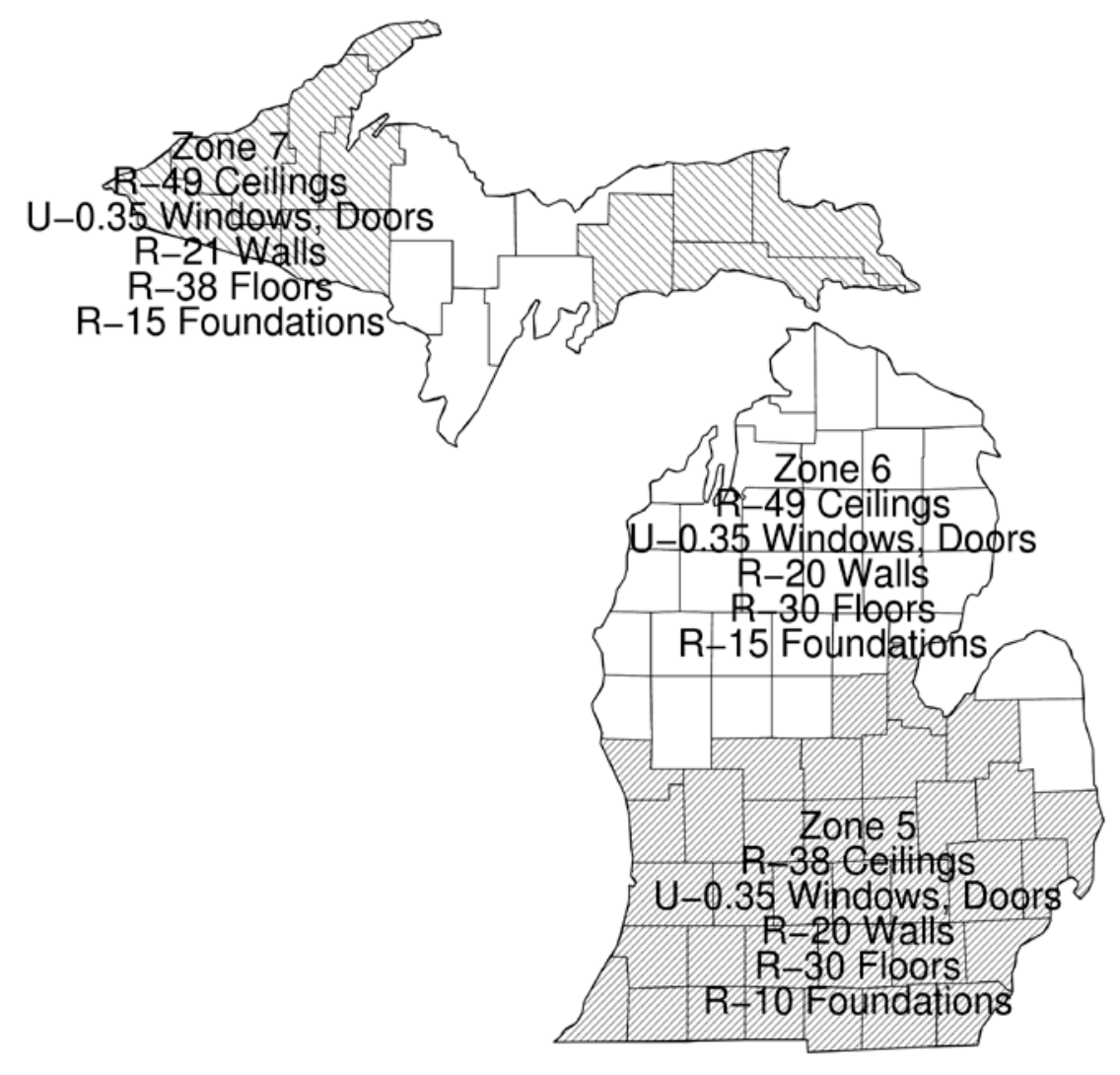

Figure 2.1. Prescriptive Envelope Requirements in the 2009 IECC

\subsection{Differences Between the MUEC and the 2009 IECC}

The Michigan Uniform Energy Code is based on Chapter 11 of the 2003 International Residential Code (ICC 2003) with substantial revisions. The MUEC allows alternative compliance via the 2003 IECC or by meeting Energy Star Homes criteria of an 85 or lower HERS Index (without the thermal bypass checklist). This analysis will focus on the requirements directly in the MUEC rather than the IECC or the more stringent Energy Star alternatives. The current MUEC and the 2009 IECC have much in common in terms of requirements. This section will identify the key differences between the two.

Like the IECC, the MUEC has prescriptive requirements that contain envelope specifications based on the climate zone. The three climate zones in MUEC are shown in Figure 2.2. These zones are similar but not identical to climate zones 5, 6, and 7 in the 2009 IECC shown in Figure 2.1. 


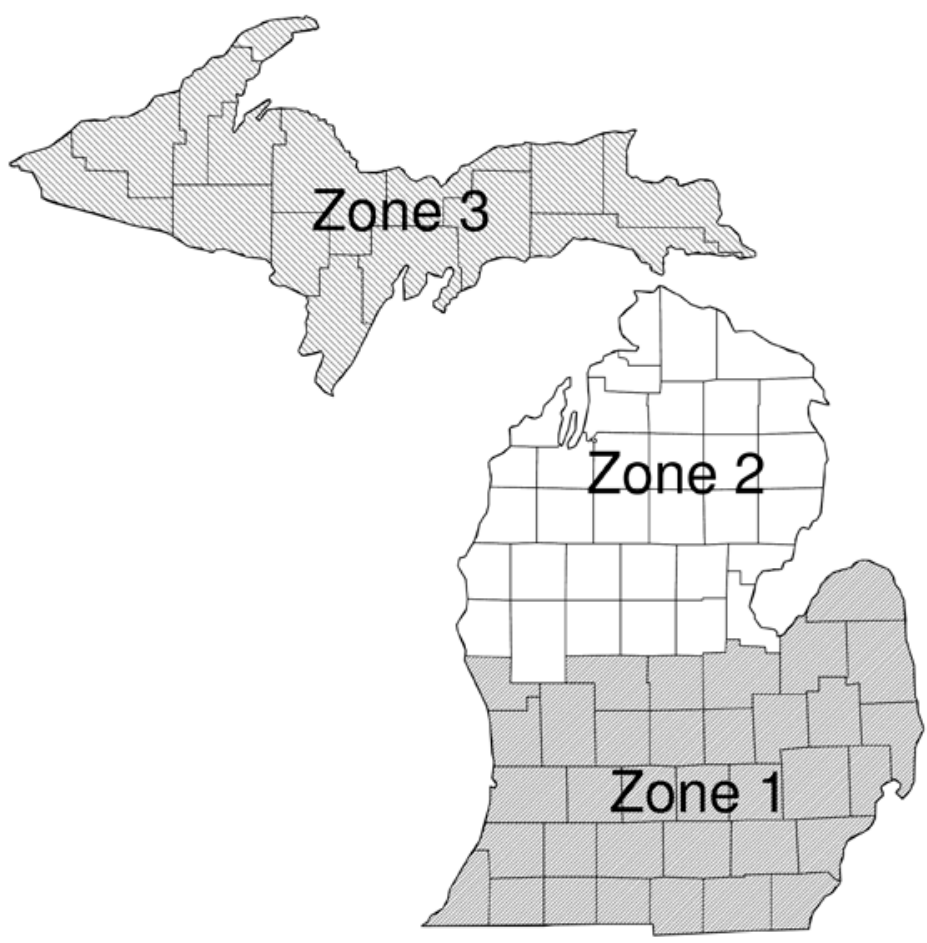

Figure 2.2. MUEC Climate Zones

The MUEC prescriptive requirements vary by the percentage of fenestration (window and door) opening area to gross wall area, whereas the IECC requirements are the same for all residential building designs irrespective of the percentage of fenestration. The prescriptive requirements for the MUEC for buildings with equal to or less than moderate window-to-wall area percentage limits are shown in Table 2.1. These limits are $15 \%$ for one- and two-family dwellings and 25\% for townhouses. The majority of all new residential buildings in Michigan should fall below these limits, although there will be a significant number of buildings that exceed these limits. The requirements in Table 2.1 were used in the energy analysis. For homes with higher window percentages, the MUEC becomes more stringent; for example, fenestration U-factors drop from 0.35 down to 0.30 or even 0.25 .

Table 2.1 also contains the 2009 IECC envelope requirements (which apply to all window/wall area percentages). The bold values show where either the MUEC is more stringent than the IECC or viceversa. Except for floor insulation, the levels required in the MUEC either equal or exceed the IECC requirements. Again, the three climate zones in the MUEC are not identical to three climate zones in the IECC, although they match up for most Michigan counties. 
Table 2.1. MUEC and 2009 IECC Prescriptive Envelope Requirements

\begin{tabular}{|c|c|c|c|c|c|c|c|}
\hline & \multicolumn{2}{|c|}{ "Zone 1 (IECC Zone 5) } & \multicolumn{2}{|c|}{ 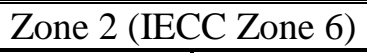 } & \multicolumn{2}{|c|}{ "Zone 3 (IECC Zone 7) } \\
\hline & & $\overline{\text { MUEC }}$ & IECC & MUEC & IECC & MUEC & $\overline{\text { IECC }}$ \\
\hline \multicolumn{2}{|c|}{ Wall Assemblies } & R-21 & R-20 & R-21 & R-20 & R-21 & $\mathrm{R}-21$ \\
\hline \multicolumn{2}{|c|}{ Fenestration/Openings } & U-0.35 & $\mathrm{U}-0.35$ & $\mathrm{U}-0.35$ & $\mathrm{U}-0.35$ & U-0.35 & U-0.35 \\
\hline \multicolumn{2}{|c|}{ Roof/Ceiling Assemblies } & R-49 & $\mathrm{R}-38$ & $\mathrm{R}-49$ & $\mathrm{R}-49$ & $\mathrm{R}-49$ & $\mathrm{R}-49$ \\
\hline \multicolumn{2}{|c|}{$\begin{array}{l}\text { Floors over unconditioned } \\
\text { spaces }\end{array}$} & $\mathrm{R}-21$ & R-30 & $\mathrm{R}-21$ & $\mathbf{R}-\mathbf{3 0}$ & $\mathrm{R}-21$ & $\mathbf{R}-\mathbf{3 8}$ \\
\hline \multicolumn{2}{|c|}{ Slab on grade construction } & $\mathrm{R}-11,4 \mathrm{ft}$. & $\mathrm{R}-10,2 \mathrm{ft}$. & R-13, 4 ft. & $\mathrm{R}-10,4 \mathrm{ft}$. & R-18, 4 ft. & $\mathrm{R}-10,4 \mathrm{ft}$. \\
\hline \multirow{2}{*}{$\begin{array}{l}\text { Crawl } \\
\text { space } \\
\text { walls }\end{array}$} & $\begin{array}{l}\text { Continuous } \\
\text { Insulation }\end{array}$ & R-20 & $\mathrm{R}-10 / 13$ & $\mathbf{R}-20$ & $\mathrm{R}-10 / 13$ & R-20 & $\mathrm{R}-10 / 13$ \\
\hline & $\begin{array}{l}\text { Cavity } \\
\text { Insulation }\end{array}$ & $\mathbf{R}-20$ & $\mathrm{R}-10 / 13$ & $\mathbf{R}-20$ & $\mathrm{R}-10 / 13$ & $\mathbf{R}-20$ & $\mathrm{R}-10 / 13$ \\
\hline \multirow{2}{*}{$\begin{array}{l}\text { Basement } \\
\text { walls }\end{array}$} & $\begin{array}{l}\text { Continuous } \\
\text { Insulation }\end{array}$ & $\mathrm{R}-10$ & $\mathrm{R}-10$ & $\mathrm{R}-10$ & R-15 & $\mathrm{R}-15$ & $\mathrm{R}-15$ \\
\hline & $\begin{array}{l}\text { Cavity } \\
\text { Insulation }\end{array}$ & $\mathrm{R}-11$ & R-13 & $\mathrm{R}-11$ & R-19 & $\mathrm{R}-19$ & $\mathrm{R}-19$ \\
\hline
\end{tabular}

Other differences between the two codes:

- The 2009 IECC contains a new requirement that buildings with ducts that pass outside the conditioned space (for example, if ducts are in unconditioned attics, garages or crawlspaces) have the ducts pressure tested and shown to have a maximum leakage rate below specified limits.

Testing is not required if all ducts are inside the building thermal envelope (for example in heated basements), although the ducts still have to be sealed. The MUEC requires ducts to be sealed but not to a specific leakage rate verified by testing as is required in the 2009 IECC.

- The 2009 IECC has a major new requirement that a minimum of 50\% of all lamps (bulbs, tubes, etc.) be "high efficacy," which is defined to include compact fluorescent lights (CFLs), T-8 or smaller diameter fluorescent tubes, or other products achieving comparable or better lumen-perwatt ratings. Traditional incandescent bulbs do not meet this requirement. The MUEC has no lighting requirements for residential buildings.

- The Michigan code requires R-5 insulation for ducts in unconditioned spaces. The 2009 IECC requires R-6 for ducts in unconditioned spaces, except for supply ducts in attics, which need R-8.

- The IECC has miscellaneous requirements not addressed in the MUEC

0 a certificate must be posted near the electrical panel listing insulation levels and other energy efficiency measures

o controls for driveways/sidewalks with snow melt systems 
o pool covers for heated pools

o fireplaces must have doors and outside combustion air.

- The Michigan code contains a "systems analysis" compliance method (Section N1105) that is more concise than the comparable approach in Section 405 of the 2009 IECC. The more detailed, more stringent, and less flexible ground rules in the IECC tend to make the IECC more energy efficient than the MUEC for many building designs if the optional systems analysis approach is used. For example, the IECC system analysis approach penalizes high window area percentages and gives less credit for testing tight building envelope air leakage. Windows can never exceed an area-weighted U-factor of 0.48 in Zone 5 and 0.40 in Zone 6 and 7. As mentioned earlier, the IECC gives no credit for improved heating and cooling equipment efficiency. This last change is particularly noteworthy. For example, the IECC will not allow reductions in envelope insulation levels if a highly efficient furnace is used. This will have a substantial impact on the flexibility allowed by the REScheck ${ }^{\mathrm{TM}}$ software and other energy performance analysis tools. 


\subsection{Assumptions Used in the Analysis}

The EnergyGauge ${ }^{\mathrm{TM}}$ software was used to determine the energy impacts of changes in envelope requirements. EnergyGauge ${ }^{\mathrm{TM}}$ is based on the DOE-2 energy simulation software developed by DOE (Parker et al. 1999).

Two different house designs were considered:

- A two-story home, 30 feet wide and 40 feet long with a conditioned floor area of 2,400 $\mathrm{ft}^{2}$ excluding the basement. It was assumed that the upper two floors of the house had 9-ft-high ceilings, a ceiling area (bordering the unconditioned attic) of $1,200 \mathrm{ft}^{2}$, a gross exterior abovegrade wall area of 2,380 $\mathrm{ft}^{2}$. The home had a heated basement with a $8 \mathrm{ft}$ high ceiling with wall area of $1,120 \mathrm{ft}^{2}$. It was assumed that the house had a total opaque (non-glass) door area of $42 \mathrm{ft}^{2}$ (two doors) and a window area of $378 \mathrm{ft}^{2}$ (15\% of the above-grade wall area). $168 \mathrm{ft}^{2}$ of supply ducts are assumed to be in unconditioned spaces, all return ducts are assumed to be in the basement (Hendron 2008).

- A one-story home, 30 feet wide and 50 feet long with a conditioned floor area of $1,500 \mathrm{ft}^{2}$ excluding the basement. The gross exterior above-grade wall area was $1,360 \mathrm{ft}^{2}\left(8 \frac{1 / 2}{\mathrm{ft}}\right.$. ceilings) and a basement wall area of 1,280 $\mathrm{ft}^{2}$. The total opaque (non-glass) door area was $42 \mathrm{ft}^{2}$ (two doors) and the window area was $216 \mathrm{ft}^{2}$ (15\% of the above-grade wall area). All ducts are assumed to be in the heated basement (Hendron 2008).

A major difference in the IECC compared to the current Michigan code is the duct sealing and insulation requirements. However, these differences only apply if ducts pass outside the unconditioned space. Many new homes in Michigan with heated basements may have the duct system entirely inside the conditioned spaces. This report considers ducts to pass outside the conditioned space for the two-story home to focus on when the code update has the most impact, even if this is in a minority of homes.

Fuel costs were obtained from DOE Energy Information Administration data for Michigan. Heating is assumed to be by natural gas. The average fuel cost of $\$ 10.72 / \mathrm{MBtu}$ from the winter of 2008/2009 was used (http://tonto.eia.doe.gov/dnav/ng/ng_pri_sum_dcu_SMI_m.htm). The average Michigan residential electricity price of 11.54 cents/kWh for the summer of 2008 (2009 data is not available yet although yearto-year electricity prices are trending higher) was used for air conditioning (http://www.eia.doe.gov/cneaf/electricity/epm/table5_6_a.html).

The envelope measures in Table 2.1 were assumed in the analysis. A number of minor differences in code requirements were not accounted for because product availability for meeting these requirements is expected to result in the same products being used in most cases. Specifically, the IECC requires R-20 insulation for above-grade walls in Zones 5 and 6 but because fiberglass batt insulation is sold at the R-21 level but not at R-20, this was assumed for IECC compliance. Additionally, the MUEC requires R-11 basement wall insulation in Zones 1 and 2. R-13 fiberglass insulation is now widely available than R-11 and has the same cost as R-11 (R.S. Means 2008). Therefore, R-13 was assumed for basements walls for the MUEC in these zones. 
The 2009 IECC contains a new requirement that buildings with ducts that pass outside the conditioned space (for example, if ducts are in unconditioned attics, garages or crawlspaces) have the ducts pressure tested and shown to have a maximum leakage rate below specified limits. While the MUEC also requires ducts to be sealed, the addition of a specific leakage limit verified by a pressure test in each new home or retrofit is expected to substantially reduce leakage in many if not most cases. Completed homes in Washington State, where prescriptive code requirements for duct sealing apply without any testing to confirm compliance, "showed no significant improvement” over non-code homes (Washington State University 2001). Another study from Washington State concluded: “Comparisons to air leakage rates, reported elsewhere for homes built before the implementation of the 1991 Washington State Energy Code, show no significant improvement by the general population” despite years of training emphasizing duct sealing (Hales et al. 2003).

Numerous other studies around the nation show substantial duct leakage in new homes, including those in states with codes requiring duct sealing (without testing). For example, a 2001 study of 186 houses built under the Model Energy Code in Massachusetts reported "serious problems were found in the quality of duct sealing in about 80\% of these houses" (Xenergy 2001). Pressurization tests in 22 of these houses found an average leakage to the outside of the house of $183 \mathrm{cfm}$, or $21.6 \%$ of the system flow, at a pressure of 25 Pascals.

The energy savings of improved duct sealing are very substantial. A California study estimated a salesweighted state annual average savings from duct sealing of 38 therms and $239 \mathrm{kWh}$ for a $1761 \mathrm{ft}^{2}$ house (Hammon and Modera 1999). This is based on an estimated 12\% improvement in duct efficiency based on previous studies indicating a 12-15\% improvement potential. This analysis assumes a $10 \%$ savings on both the heating and cooling energy use from improved duct sealing needed to meet the IECC leakage limits.

High-efficacy lighting was assumed to increase from $10 \%$ (most houses have some degree of efficient fluorescent lighting in laundry rooms, garages etc.) to the IECC requirement of $50 \%$ of all lighting within the building, reducing lighting energy use by $26 \%$, or $\$ 71$ a year for the $2400 \mathrm{ft}^{2}$ house and $\$ 50$ a year for the $1500 \mathrm{ft}^{2}$ house. Savings attributable to the lighting requirements in the IECC will decrease as Federal law requires improved light bulbs in 2012 to 2014. 


\subsection{Impacts from Adopting the 2009 IECC in Michigan}

The assessment of the impacts from adopting the 2009 IECC includes construction costs impacts, energy savings, mortgage-related cost impacts to consumers, life-cycle cost impacts, and aggregate statewide impacts.

\subsection{Construction Cost Impacts}

Estimating construction costs is the most difficult and uncertain step in assessing the cost effectiveness of energy codes. Costs can vary greatly depending on the builder, subcontractors, and materials and equipment suppliers. Costs may decrease after the market adapts to the code requirements and the energy-efficient products required by the code become prevalent. While costs may vary, the costs assumed here are based on documented sources and are considered reasonable estimates. The costs reported here include the builder's profit and represent the sales value of the house.

R.S. Means Cost data (2008) was used to estimate insulation costs. For ceiling insulation, the 2009 reports 16 cents/ft ${ }^{2}$ for the improvement from R-38 to R-49 using fiberglass batts. This assumes R-49 is achieved through a combination of R-30 and R-19 batts. R-19 basement wall insulation was estimated to cost 11 cents $/ \mathrm{ft}^{2}$ for the improvement compared to R-11.

Duct insulation costs vary depending on the duct system layout and the duct type and R-value. The Home Depot web site on September 9, 2009 reports a cost increase of \$0.35 per linear ft. for R-8 flex duct compared to R-6 (6 in. ducts) (products with other R-values were not available). The installed cost for $1 \mathrm{in}$. of duct wrap insulation is $\$ 2.23 / \mathrm{ft}^{2}, 1 \frac{1}{2} \mathrm{in}$. costs $\$ 2.46 / \mathrm{ft}^{2}$ according to $\mathrm{R}$. S. Means (2008). Given these types of costs, the incremental cost of R-6 or R-8 instead of R-5 for supply ducts should be relatively small, even including an increase in installation cost, overhead and profit. Therefore, a cost of $\$ 200$ was assumed to insulate 168 linear $\mathrm{ft}$. of attic supply ducts for the $2400 \mathrm{ft}^{2}$ house. No cost (or energy savings) impacts are assumed for $1500 \mathrm{ft}^{2}$ house because all ducts are assumed to be in the heated basement and therefore not insulated.

Hammon and Modera (1999) estimate a cost of \$214 for materials and labor related to improved duct sealing plus $\$ 131$ to $\$ 163$ for testing and suggest costs will be even lower in a mature market. This does not account for possible cost savings from downsizing HVAC systems because of decreased design loads. Even with the conservatively low California energy savings estimate, this is a simple payback of 5.1 to 5.6 years. The Journal of Light Construction (Uniacke 2003) quotes an even lower total cost of \$220, which indicates a simple payback of under 4 years. Duct pressurization testing equipment commonly known as “duct blasters” cost about \$1500-2000 (Sherman, 2004, PDF page 171). Presumably, this equipment would come down in price as the market for this equipment grows. A cost of $\$ 400$ was assumed here for testing and for improved sealing necessary to safely pass the maximum allowed leakage level. The duct testing and improved duct sealing do not apply to the $1500 \mathrm{ft}^{2}$ house because all ducts are assumed to be inside the conditioned space. 
Efficient lighting can be achieved by the use of compact fluorescent lighting, although other lighting options qualify as well. Compact fluorescent bulbs are available at a modest cost; the Energy Star website estimates a cost of $\$ 3.40$ per bulb (http://www.energystar.gov/index.cfm?c=cfls.pr_cfls, see Savings Calculator). The cost of meeting the IECC lighting requirements is estimated at $\$ 100$ per house. Given the clear cost effectiveness of energy efficient lighting and the fact that upcoming Federal light bulb standards will soon minimize the impact of the 2009 IECC lighting requirements, no further analysis of the cost/benefit of lighting is included in this report.

Table 4.1 summarizes these construction costs for the major energy efficiency measures required by the 2009 IECC compared to the current Michigan code. The negative cost for ceiling insulation in Detroit indicates the IECC is less stringent than the Michigan code. Note again that other combinations of improvements in energy efficiency measures can be used to comply with the 2009 IECC and might have a different cost. Additionally, actual construction costs related to IECC compliance will vary from those in this report depending on differences in the building size and design.

Table 4.1. Construction Costs (Incremental Relative to MUEC requirements) for 2009 IECC Energy Efficiency Measures

\begin{tabular}{|l|l|l|l|l|l|l|}
\hline \multirow{2}{*}{} & \multicolumn{2}{|c|}{ Zone 1 (IECC Zone 5) } & \multicolumn{2}{c|}{ Zone 2 (IECC Zone 6) } & \multicolumn{2}{|c|}{ Zone 3 (IECC Zone 7) } \\
\cline { 2 - 8 } & $\mathbf{2 4 0 0} \mathbf{f t}^{2}$ & $\mathbf{1 5 0 0} \mathbf{f t}^{\mathbf{2}}$ & $\mathbf{2 4 0 0} \mathbf{f t}^{2}$ & $\mathbf{1 5 0 0} \mathbf{f t}^{\mathbf{2}}$ & $\mathbf{2 4 0 0} \mathbf{f t}^{\mathbf{2}}$ & $\mathbf{1 5 0 0} \mathbf{f t}^{\mathbf{2}}$ \\
\hline \hline $\begin{array}{l}\text { Ceiling } \\
\text { insulation }\end{array}$ & $-\$ 192$ & $-\$ 240$ & 0 & 0 & 0 & 0 \\
\hline $\begin{array}{l}\text { Basement } \\
\text { insulation }\end{array}$ & 0 & 0 & $\$ 123$ & $\$ 141$ & 0 & 0 \\
\hline $\begin{array}{l}\text { Duct } \\
\text { insulation }\end{array}$ & $\$ 200$ & 0 & $\$ 200$ & 0 & $\$ 200$ & 0 \\
\hline $\begin{array}{l}\text { Duct sealing } \\
\text { and testing }\end{array}$ & $\$ 400$ & 0 & $\$ 400$ & 0 & $\$ 400$ & 0 \\
\hline TOTAL & $\$ 408$ & $\$-240$ & $\$ 723$ & $\$ 141$ & $\$ 600$ & $\$ 0$ \\
\hline \hline
\end{tabular}

\subsection{Energy Savings}

Table 4.2 shows the annual energy use (space heating and cooling only) that will result from complying with the IECC requirements and current practice, and the savings over current practice. The cities are representative of the three IECC and MUEC climate zones. 
Table 4.2. Annual Heating and Cooling Energy Cost and Savings from Compliance with IECC

\begin{tabular}{|l|l|l|l|l|l|l||}
\hline \multirow{2}{*}{} & \multicolumn{2}{|c|}{ Detroit } & \multicolumn{2}{c|}{ Traverse City } & \multicolumn{2}{c|}{ Houghton } \\
\cline { 2 - 7 } & $\mathbf{2 4 0 0} \mathbf{f t}^{\mathbf{2}}$ & $\mathbf{1 5 0 0} \mathbf{f t}^{\mathbf{2}}$ & $\mathbf{2 4 0 0} \mathbf{f t}^{\mathbf{2}}$ & $\mathbf{1 5 0 0} \mathbf{f t}^{\mathbf{2}}$ & $\mathbf{2 4 0 0} \mathbf{f t}^{\mathbf{2}}$ & $\mathbf{1 5 0 0} \mathbf{f t}^{\mathbf{2}}$ \\
\hline \hline IECC & $\$ 1005$ & $\$ 668$ & $\$ 1122$ & $\$ 741$ & $\$ 1190$ & 0 \\
\hline MUEC & $\$ 1104$ & $\$ 646$ & $\$ 1286$ & $\$ 783$ & $\$ 1330$ & 0 \\
\hline $\begin{array}{l}\text { Total } \\
\text { Savings }\end{array}$ & $\$ 99$ & $-\$ 22$ & $\$ 164$ & $\$ 42$ & $\$ 140$ & 0 \\
\hline $\begin{array}{l}\text { Percent } \\
\text { Savings }\end{array}$ & $9 \%$ & $\begin{array}{l}3 \% \\
\text { (increase) }\end{array}$ & $13 \%$ & $15 \%$ & $11 \%$ & 0 \\
\hline
\end{tabular}

\subsection{Economic Impacts as specified by the Stille-DeRossett-Hale Single State Code Construction Act}

The Stille-DeRossett-Hale Single State Code Construction Act sets the following conditions for Michigan energy efficiency standards:

(i) The analysis shall take into consideration the perspective of a typical first-time home buyer.

(ii) The analysis shall consider benefits and costs over a 7-year time period.

(iii) The analysis shall not assume fuel price increases in excess of the assumed general rate of inflation.

(iv) The analysis shall assure that the buyer of a home who qualifies to purchase the home before the addition of the energy efficient standards would still qualify to purchase the same home after the additional cost of the energy-saving construction features.

(v) The analysis shall assure that the costs of principal, interest, taxes, insurance, and utilities will not be greater after the inclusion of the proposed cost of the additional energy-saving construction features required by the proposed energy efficiency rules as opposed to the provisions of the existing energy efficiency rules. 
Because most houses are financed, consumers will be very interested in the financial impacts of buying a home that complies with the 2009 IECC requirements. Mortgages spread the payment for the cost of a house over a long period of time. In this analysis, a fixed-rate mortgage was assumed. It was also assumed that homebuyers will deduct the interest portion of the payments from their income taxes.

The financial and economic parameters required for input to this analysis are summarized below. These parameters are used to calculate the costs and benefits of increased energy efficiency from the homeowner's perspective.

- $\quad$ New-home mortgage parameters:

o $\quad 6.0 \%$ mortgage interest rate (fixed rate)

0 points and loan fees equal to $1.6 \%$ of the mortgage amount

o 30-year loan term

o 20\% down payment.

o $\quad 0.7 \%$ annual private mortgage insurance ${ }^{2}$

- Other rates and economic parameters:

o $6 \%$ nominal discount rate (equal to mortgage rate)

$015 \%$ marginal federal income $\operatorname{tax}^{3}$ (it is assumed that tax deduction for mortgage is utilized), $4.35 \%$ state income tax ${ }^{4}$

o $1 \%$ property tax ${ }^{5}$

o $2 \%$ inflation rate ${ }^{6}$

o 7 year analysis period, no residual/salvage value.

Table 4.3 shows the impacts to consumers' cash flow resulting from IECC compliance. In two cases the IECC does not increase construction costs so the code impacts are listed as not applicable (NA). The up-front costs include the down payment, points, and loan fees. The savings from income tax deductions for the mortgage interest will slowly decrease over time. The annual values shown in the table are for the first year. The net annual cash flow includes energy costs, mortgage payments, mortgage tax deductions, and property taxes but not the up-front costs.

\footnotetext{
${ }^{2}$ From: http://en.wikipedia.org/wiki/Lenders_mortgage_insurance

http://en.wikipedia.org/wiki/Income tax in the United States\#Year 2008 income brackets and ta x_rates

${ }^{4}$ http://www.bankrate.com/brm/itax/edit/state/profiles/state_tax_Mich.asp

${ }^{5}$ From: http://www.michigan.gov/taxes/0,1607,7-238-43535 43540---,00.html Also see

http://www.taxfoundation.org/taxdata/topic/36.html. Property taxes can vary by location.

${ }^{6}$ From: http://www.federalreserve.gov/monetarypolicy/fomcminutes20090624.htm
} 
Table 4.3. Impacts to Consumers' Cash Flow from Compliance with 2009 IECC

\begin{tabular}{|l|l|l|l|l|l|l||}
\hline & \multicolumn{2}{|c|}{ Detroit } & \multicolumn{2}{c|}{ Traverse City } & \multicolumn{2}{c|}{ Houghton } \\
\hline \hline & $\mathbf{2 4 0 0} \mathbf{f t}^{\mathbf{2}}$ & $\mathbf{1 5 0 0} \mathbf{f t}^{\mathbf{2}}$ & $\mathbf{2 4 0 0} \mathbf{f t}^{\mathbf{2}}$ & $\mathbf{1 5 0 0} \mathbf{f t}^{\mathbf{2}}$ & $\mathbf{2 4 0 0} \mathbf{f t}^{\mathbf{2}}$ & $\mathbf{1 5 0 0} \mathbf{f t}^{\mathbf{2}}$ \\
\hline \hline Up-Front Costs & $\$ 86$ & $\mathrm{NA}$ & $\$ 153$ & $\$ 30$ & $\$ 127$ & $\mathrm{NA}$ \\
\hline $\begin{array}{l}\text { Annual Energy } \\
\text { Savings }\end{array}$ & $\$ 99$ & $-\$ 22$ & $\$ 164$ & $\$ 42$ & $\$ 140$ & $\mathrm{NA}$ \\
\hline $\begin{array}{l}\text { Annual Mortgage } \\
\text { Increase }\end{array}$ & $\$ 25$ & $\mathrm{NA}$ & $\$ 43$ & $\$ 8$ & $\$ 36$ & $\mathrm{NA}$ \\
\hline $\begin{array}{l}\text { Net Annual Cash } \\
\text { Flow Savings (year } \\
\begin{array}{l}\text { 1, excluding up- } \\
\text { front costs) }\end{array}\end{array}$ & $\$ 67$ & $\mathrm{NA}$ & $\$ 108$ & $\$ 31$ & $\$ 94$ & NA \\
\hline $\begin{array}{l}7 \text { year net present } \\
\text { value savings }\end{array}$ & $\$ 337$ & $\mathrm{NA}$ & $\$ 535$ & $\$ 166$ & $\$ 469$ & NA \\
\hline
\end{tabular}




\subsection{Conclusion}

If the 2009 IECC were adopted by the state of Michigan, a modest improvement is expected in the energy efficiency of residential buildings. The main impact is from improved duct sealing verified by duct system leakage testing and increased duct insulation. Building enclosure insulation levels and window requirements are largely unchanged from the current state code, although the 2009 IECC has a decrease in ceiling insulation in the southern part of the state compared to the current state code. While the initial cost of construction will often rise, energy bills will be reduced. Construction cost increases and energy savings will vary depending on many factors, including location, fuel prices, house size and characteristics, material and labor costs, and the energy efficiency measures used to comply with the 2009 IECC.

The analysis concludes that homes built to meet the 2009 IECC requirements will save Michigan homeowners money by reducing energy costs by more than the construction-related cost increases over a 7-year time frame. Homeowners should generally realize a net positive cash flow within a few years after accounting for the effects of a typical mortgage 


\subsection{References}

Hales, D., A. Gordon, and M. Lubliner. 2003. 2003. Duct Leakage in New Washington State Residences: Findings and Conclusions. ASHRAE. Atlanta, Georgia.

Hendron, R. 2008. Building America Research Benchmark Definition. NREL/TP-550-44816. National Renewable Energy Laboratory. Golden, Colorado.

Hammon, R. W., and M. P. Modera. 1999. "Improving the Efficiency of Air Distribution Systems in New California Homes-Updated Report.” ConSol. Stockton, California.

International Code Council (ICC). 2003. 2003 International Residential Code. Falls Church, Virginia.

International Code Council (ICC). 2009. 2009 International Energy Conservation Code. Falls Church, Virginia.

Parker, D. et al., 1999. "EnergyGauge ${ }^{\circledR}$ USA: A Residential Building Energy Simulation Design Tool,” Proceedings of Building Simulation '99, International Building Performance Simulation Association, Organizing Committee for the $6^{\text {th }}$ International IBPSA Conference, Department of Architecture Texas A\&M University, TX.

R. S. Means Company, Inc. (Means). 2008. Means Residential Cost Data--2009, 28th Annual Edition. Kingston, Massachusetts.

Sherman et al. 2004. Instrumented HERS and Commissioning. http://www.energy.ca.gov/pier/final_project_reports/500-04-012.html

Uniacke, M. Journal of Light Construction. April 2003. "Pressure-Testing Ductwork.”

U.S. Department of Energy (DOE). 1995. 1995 MECcheck ${ }^{T M}$ Manual, 1992 Model Energy Code Compliance Guide, Version 2.0. Building Standards and Guidelines Program, Pacific Northwest National Laboratory, Richland, Washington.

Washington State University. 2001. Washington State Energy Code Duct Leakage Study Report. WSUCEEP01105. Washington State University Cooperative Extension Energy Program, Olympia, Washington.

Xenergy. 2001. Impact Analysis of the Massachusetts 1998 Residential Energy Code Revisions. http://www.mass.gov/Eeops/docs/dps/inf/inf_bbrs_impact_analysis_final.pdf 